\title{
The Character of a Beautiful Girl in Vietnamese Fairy Tales
}

\author{
Dang Quoc Minh Duong ${ }^{1 *}$, Duong My Tham ${ }^{1}$, Tran Minh Hau ${ }^{1}$ \\ ${ }^{1}$ Van Hien University, Vietnam \\ *Duongdqm@vhu.edu.vn
}

\section{ABSTRACT}

The beautiful girl is a character of high frequency in Vietnamese fairy tales. Folklores develop this character comprehensively, from the origin to appearance and spirit. Regarding the appearance, this character is fair-skinned and has pretty small feet. Spiritually, this character has typical personality traits of a traditional Vietnamese woman, such as diligence, loyalty, and filial piety. An examination of this character can help make an insight into Vietnamese perceptions of beauty.

Keywords:

Beautiful girl, Vietnamese fairy tales, appearance, white-skin, spirit.

\section{Introduction}

Pretty characters - especially the beauties, are always a subject matter for exploitation and researches of various types of arts, particularly of sculpture, painting, movies, and literature. However, no one has studied the beautiful heroines in folklore - especially in legends. There have been a few general observations as that by V. Ia. Propp, saying that: "legends do not involve the art of portrait" (Multi-authors, 2004, p. 418). Duc Xuan Nguyen has referred this comment in his work "Prosody on Vietnamese folklore and legends. Furthermore, we have recently instructed Luan Thanh Nguyen to successfully protect his Master thesis on the Beauties in Vietnamese legends; he has also had his way to study closer on these characters. We have not had any conditions, however, to get further into highlighting their appearance, nor have we made any generalization or linked the beauty of the characters' souls with Vietnamese culture.

From this fact, and with analyzing and synthesizing methods in researches - especially interdisciplinary researches, we are going to study Vietnamese legends to find out the presence of this kind of characters to highlight the points that we have mentioned above. Specifically, the work will explore some issues, such as the origin of the characters, their good-looking appearance, and their beautiful inner.

\section{Content the Character' Background}

Studies on the background of beautiful heroines in Vietnamese legends have come to the findings as follows:

Some beauties come from their heavenly world. The fairly world may have exiled these beautiful characters to the earthly world (Lieu Hanh Princess), or for some other reasons; for example, someone had stolen their wings, so these women had to stay in the Earth (Chức Nư - in The Weaver Girl and the Cowherd, and Nàng Tiên - The Fairy). The causes of their presence in the world are various though, they all share the same feature: their absolute beauty, as a
Vietnamese saying goes: “as pretty as heavenly girls!”. Such origin shows the imprint of the mythological inheritance - a genre that predates and leaves much influence on the poetry of the development of characters of fairy tales, especially the sub-genre of mystical legends.

Some beautiful female characters are members of the royal families, of courtiers or affluent families. These characters appeared in the period when social classes had come to existence. Coming from wealthy families, these beauties shall obviously lead a materially affluent life, with plenty of privileges. Unlike ordinary people, they do not have to work in the fields, so they usually keep a beautiful complexion. Folks, although have a prejudice against members of this class, and bear no sympathy for them, they at the same time dream and desire to have such a life. This is a dialectical but very realistic view.

Some others are beauties of civilians. They are ordinary - or even rank-and-file members in the society, those run-of-the-mill and oppressed workers are like the girls in the Story of Betel, Areca and Lime, and Story of the "Ba Rau" Rock (Rock of Querulous Dame), etc. Being common people, in reality, these girls may not be very good-looking, but they always have their dreams of a better life. Folk artists always know how to make these characters more beautiful. That is human nature in people's creativity. In number, beautiful girls with this background count for the highest proportion. Thus along with the dream of an equal society and a divine humanism, our foregoers have paid attention to those with low status in society.

Through the background that we have mentioned above, we have found that: while people show an upward view of an ideal world; they also have an equal, democratic view that beauty is not a prerogative of an individual or a class of people. Yet we people all possess this thinking. It is the first trait of beautiful girl characters. 


\section{The exquisiteness of the characters' appearances}

After introducing their characters' backgrounds, folk artists quickly provide us with information about their appearances. It is the information, or more precisely, a short statement, like "that family/village/king has a very pretty daughter." This declaration is redundant yet insufficient! Redundant, because having been known as a beautiful girl, she must be announced as such as a matter of fact. Insufficient, because the declaration does not provide enough information as the readers often expect. Indeed, the first feeling one gets when having read these stories is why were the authors so reticent? As with this beauty, those folk artists should have given it a few pages or at least a few paragraphs, or a few sentences to describe their charm. When describing those beauties, folk songs give us a closer look with "pink cheeks," "dimpled cheeks," or "black teeth," "fair-skinned long-haired," "phoenix's eyes and red lips, etc. Whereas with legends, the only thing we know is that those girls are beautiful, but as how beautiful they are, they fail to specify. Experts have long noticed this when they point out that, on prosody, authors of legends did not intent to portrait their characters. Instead, they focus on the actions of these characters.

People typically do not pay attention to describing in detail the appearance of their characters, but closer examination enables us to see one fact. Seldom do the authors describe the appearance of their main characters, but once do, they know how to do it and accentuate the very typical, specific features. Of the "best," the highlights of the beautiful fair skin and petite feet of the beauties impress us as readers.

Beautiful and white complexion: as in people's concept, "posture comes first, second the skin." The standard of beautiful posture varies over time, but to be beautiful, one must be of fair complexion. That is why we find nothing strange when we refer to such beautiful female folk characters with white complexion: "She became white and pretty" (The legend of monkeys); "A girl with fair skin and red lips, worm-like eyebrows and phoenix eyes bewilders him." (The man who married a toad); "The flower-like beautiful girl with white-powdered skin" ( $A$ scented shoe). The story on "Tam and Cam" by Chi Dong Nguyen does not mention Tam's beauty, but the version by Phan Ngoc $\mathrm{Vu}$ and the narratives numbered 9, 10, 11, 13 and 14 in Bac Lieu all mention this detail: when having seen Tam again, "Cam saw that Tam had returned to be more beautiful and fairer" (Dac Tan Nguyen, 2013, pp. 266 298). So, being white-skinned here is the number one and the first criterion to value a girl's appearance. The story "Please buy my shallots!" tells us more about this process: in the past, the farmer's wife "was also a farmer, getting an awful sweat all year round, and was dark in skin and quite ugly". After she anointed herself with magic water, "she became pretty white, and beautiful that almost second to none." We can see this confrontation again in the story of Ha O Loi. Even the queen - Snow White's mother - living in Europe where the people prefer tanned skin, she once dreamed, "I wish I had a snow-white child" (Snow White and the Seven Dwarfs). This seems to be a dream not only from Asian Vietnamese but also from Europeans. Thus, to a certain extent, black is synonymous with ugly, while white homogeneous with beautiful.

Vietnamese peoples, in particular, peoples of East Asia, North Asia, East Central Asia, in general, belong to the Mongoloid race. They carry typical characteristics of the great Asian Race: small eyes, slightly slanted and medium nose, high cheekbones, black straight hair, pale yellow skin. So why do Vietnamese people appreciate white skin as the highest criterion when evaluating a beauty's appearance?

Biologically, researchers have assumed that the change in skin pigmentation of Han Chinese is a result of the OCA2 gene mutation. According to Su Bing, Meng Anming, and his team: this mutation occurred when Han ancestors migrated from Southwest and Southeast Asia to the north about 25,000 to 30,000 years ago. In this area, due to the lack of sunlight, the OCA2 gene stimulated more sunlight absorption to avoid the deficiency of vitamin D, helping people adapt to the new climate (Su B., Meng A. \& ..., 2016, p. 1182). People with gene mutations have their skin fairer than usual. This study finding applies not only for Han Chinese but also for the Great Asian race.

Initially, people of gene mutation stood out from common yellow skin; along time and under cultural conditions they gradually developed a preference for fair skin. Being the inhabitants of Wet Rice Agriculture, they may have felt that having dark skin resulting from working in the fields was synonymous with being in lower classes. Only those who have lead an affluent life and enjoy living in the lap of luxury can own white skin. As a result, people especially women, always have a burning dream of fair skin. This obsession is not only found in Asian women but also in African women, not only in ancient legends but also maintained up to our modern-day. A dream of having beautiful white skin is also that of a life of no longer toiling away in the fields, and of a happy, warm and tranquil life. Thus, behind the dream of fair skin is clearly an ambition of changing life, even changing destiny.

The racist ideology and colonialism in the United States and European countries also reinforced this preference for white skin. According to this ideology, only white people were "superior" and senior to the others. Consequently, the whites should rule over colored peoples, immigrants, Jews, and Catholics. It is an extremist ideology worthy of condemnation, but unfortunately, it still exists today.

About the pretty petite shoes/feet: Different versions of the legend of Tam Cam in Vietnam or the Cinderella story in many countries around the world, all have details describing the shoes so cute and small that no other girl's feet can fit; they only fit pretty little feet. Besides the type of Tam Cam story, in our surveyed subjects we also find quite special details in the story of The scented shoe. In the story, when Ly Quoc Hoa had failed to keep an appointment with miss Truong, he "took out the shoe and lovingly cared of it (...) They went to the bridge and found his dead body hugging a fragrant shoe onto his chest." Here, Ly Quoc Hoa had considered the shoe as miss Truong. Back 
to the Tam Cam story, the strangely beautiful little shoe made the prince curious and determined to find the girl who wore that shoe. So in the narratives of Vietnam and Southeast Asian countries, there are always details about girls trying on the shoe to see whoever fits it will be married by the prince and to be queen. When mentioning shoes, people are clearly referring to beautiful feet and charming girls. That is why Nguyen Du once described Kieu's feet as if made of lotus, saying: The steps of lotus-made feet seem adjacent but also like in the distance (Kieu Story).That is art, that is folk creation. According to Dac Tan Nguyen, "this petite foot motif is certainly under the influence of the foot binding custom that has existed for a long time in Chinese culture." Thus, according to popular conception, beautiful little feet are the symbol of a beautiful girl - both in appearance and virtue.

Thus, legends are truly very reticent in portraying characters. But, when need to make it apparent, folk authors know how to choose specific details to convey the message. Here again, we see the value of the genius remarks by V. Ia. Propp, that: in legends, "we either completely ignore the appearance of characters, or represent only a few details of the characteristics of a definite type of persons rather than of an individual. "(multi-authors, 2004, p. 418).

\section{The inner beauty of characters}

Folk writers not only describe the outer beauty of their female characters, they also develop the beauty of their soul. Therefore, from the outset, when bringing the appearance of the character in, the legend's author starts revealing their inner beauty. For example, in the story of Durian Fruit, the heroine "has a sweet beauty," whereas the story of Nũ hành giành bac describes the female character as "greatly beautiful, well-learned, and demure;" or the story of the Virgin with two Husbands mentions a pretty girl with good temperament and of virtue; or in The woman unjustly accused, the woman appears as "good-looking, well-behaved, a good example of a decent woman". Generally speaking, those women were gentle, decent, modest, and virtuous. Set in the background of Vietnam - a country under heavy influence of Confucian culture, we will see that these characters have all the qualities of traditional Vietnamese women -the three submissions, and the four virtues (be industrious, beautiful, good at speech, and demure). We will discuss these virtues in more details.

Công is being industrious with one's housework as in sewing, embroidery, kitchen work, and one's daily chores. In Eastern conception in general, especially in Vietnamese people's, these are the "Household Interior Minister's" jobs. This conception has it that: if a family has a wife/mother who is good at her routine, her husband and children will be in good shape and warm clad, and the family will be neatly in good order. Therefore, Ms Tam - with pure Vietnamese beauty, must be good at catering functions for members of the family; she should know how to take care of the family's cattle, to prepare offerings in worshipping ancestors, and to prepare pieces of betel in phoenix-winged shape. The toad wife (The one that married a toad) not only knew how to guard the fields, but was also very skillful in preparing banquets, sewing clothes, and so on. So she won victories in the competitions that the students of a Confucian teacher had hosted. Not only such things, some other beauties also showed other abilities in such business as trading and government affairs. For example, Princess Tiên Dung (The legend of One Night lagoon and Nature beach), was good at trading and bartering and turned the desolate area Ha Tham into a busy and prosperous city. Similary, Ms. Nguyen Thi Bich Chau was also well-educated and good at writing. She often helped the king with his paperwork or even reminded and helped him adjusting his rules over the country. Asides from the above mentioned targets, we can also encounter the word "Công" in some other stories such as The Stupid Guy, the Smart Bride, and so on.

Virtue is a woman's loyalty and respect for her husband. Nguyen Dinh Chieu considered this to be the most important value that a woman should keep in mind: "As for a young man, loyalty to one's king, and love and respect to one's parents should be the first rate norms to him; as for a woman, being loyal to her husband is the sole criterion to help keep herself good." There are many ways to express a wife's virtue. Her faithfulness to her husband is one of the cases. That is why there are many stories about the virginity of virtuous wives. It was Ms. To Thi - a victim and remnant of the tragedy of incestuous marriage, in which she petrified waiting for her husband to return, "standing impassively, staring in the direction of her husband." And the wife in the Story of the Rock Ba Rau was so anxious to wait for her husband that she turned into a rock, her eyes were still staring into the endless horizon." Moreover, Ms $\mathrm{Vu}$ had always been a perfect wife and mother but her husband, Mr. Truong misunderstood her. He falsely claimed that she was not righteous. The husband unjustly accused her to the point that she sought her death to vindicate. Confucian conception demands that: "a man can marry many wives, but a woman must be honest to her only husband."

In exceptional cases, people had to find the most reasonable explanation, such as the case in the story The Virgin of two husbands. The story is about a good wife, "married to her husband as a virgin." When her husband became ill, "the wife worriedly sought a physician for medicine. She also sold her jewelry and whole garden where they were inhabiting in to treat her husband. Thinking that the husband had died, she remained unmarried and observed chastity to him. Later, obeying her mother, she got married to her new husband. When finding out that her previous husband was still alive, she secretly helped him to pass the national exam. It is a very bold creation of the people: "legalizing" the marriage to two husbands yet the wife is still considered ... a faithful one. Again, in the Story of The woman who was wrongly accused, the wife named Tình (Love) did not resign herself to injustice. Her husband's friend, the man named Ly, falsely claimed that she was unrighteous, and that she had not kept her chastity. With her sharp skills and her firm stuff, she managed to unmask her husband's shifty friend. The result: she proved her decency. She and her husband were reunited; the dealer's conspiracy came to light. Besides the mentioned stories, we can see the virtue of the beautiful female characters in many other stories such as Nũu hành giành bac, The Van lich coin, 
Mouse Ghost, Tu Uyen, Please buy my shallots, The Jar of sacred water, Predestined love when reborn, Story of the gratitude tower, or The ant that sues a sweet potato, etc.

Filial piety counts the first of hundred human conducts and is the root of virtue. Therefore, ancients took account of filial piety as the highest virtue of human dignity, i.e., of hundreds of good deeds, filial piety is at the first place. Since immemorial times, in families and societies, especially in Confucianism influenced countries as in Vietnam, people have always focused on promoting and educating children to be filial to their parents and ancestors. This is also clearly seen through beautiful female characters in legends. For instance, the youngest daughter in the story Married to a goat husband and The Coconut Skull all showed the obedience, politeness, and righteousness of children in families in response to the arrangement of their fathers, thus, "We will obey our parents' arrangement." Like the female characters in stories Predestined love when reborn, Unrequited love after death, Disintegrate Love in Propaganda, Mr. Dao, although their parents-in-law forbade their love, these women accepted the fate without any fighting against it at all. These women not only love and care for their living parents of both sides, they also memorized their dead ancestors. Ms Tam (in Tam Cam story), while living happily in the palace, "did not forget her father's death anniversary. She asked the king's permission to come back home to help her stepmother prepare offerings to worship her dad's death. Princess Tien Dung, albeit her king father had forbidden her love, and even when her father cast her away, she still treated him with reverence and piousness. Even when her King father sent soldiers to chase and catch her, and albeit her ability to fight back, she did not "dare to resist against her father".

Besides the good characteristics surveyed above, we also see in some stories, feminism started to raise its voice, especially the right to love. That is the voice of the beautiful princess in the story The daughter of the God of Waters who loved a fisherman. She loved singing and loved the fisherman. She dared to love and to live with her lover. This mindset was unacceptable those days. About the case of the girl in the story Predestined love when reborn, too, she "let her parents know that she had promised marriage with the man and would get married to him." She dared to choose the man to love and to live with him. When she knew that she could not change the situation, "she decided to risk her own life rather than having to marry someone she disliked." And, in The legend of One Night Lagoon and the Nature beach, Tien Dung Princess dared to give up the royal life, to resist against the orders of her father to love and live with a destitute man in abject poverty like Chu Dong Tu.

Beside those beauties whose charming appearance is harmonious with their souls, there are several cases of "deflection", in which their appearance is beautiful but their souls are arrogant, inhuman and poor. An example is the wife in The story of a mosquito: she ignored that her husband had saved and loved her, she changed her appearance and became beautiful. Then she stepped out on her husband and to couple with a merchant "high on the hog." Finally, this ungrateful, unworthy woman ended up with her death, and turned into a mosquito, always trying to seek and suck others' blood. The beautiful girl in The story of the Pot of slaked lime also bears the same fate: she was an arrogant girl who had "alienated herself from all her friends, male and female." After she got married to her husband, she became jealous, "always making her neighbors frown because of her words." Finally, she was divorced from her husband and left to become a nun. On the way to Tay Truc (Hsinchu), she still kept with herself the arrogance and aughty disdain. As a result, the Buddha properly punished that arrogant and cruel woman. Her body fell onto the ground and her skeleton and skull broke into pieces." Through a few cases of deflection above, our foregoers have given us their clear message: beauty really requires harmony and balance both in appearance and soul, in which, the beauty of the soul is especially indispensable.

Thus, different from describing the beauty of characters' appearance and not only modifying the subject with comments, when describing the good nature of their souls, our ancestors have completely performed detailed descriptions. In our opinion, the reason for this "priority" is that besides the beauty of appearance, the beauty of the soul has higher priority. This concept shows in the proverb "better wood than good paint" (Clothes do not make a man). Moreover, to agree that a flower is beautiful, one just needs to look over it. But to comprehend a kind person or a beautiful personality, one must have enough time to explore it, and he must have more evidence to confirm it. You will never know a man until you have eaten a peck of salt with him (as in time reveals a person's heart!)

Thus, not only the beauty of their looks, beautiful female characters also have appealing souls. Those are the beauties who are clever and industrious in their families, good in their marriage, filial to their parents, and so on. It is also the image of a traditional Vietnamese woman -of a nation under the influence of Confucian culture.

\section{Conclusion}

In short, beautiful female characters make their appearance quite popular in Vietnamese legends. Although people might not "be whole-hearted" when describing the appearance of these characters, they have selected the underlined traits of their bright skin with petite and lovely feet. Along with their physical beauty, beautiful female characters also have such characteristics of a traditional Vietnamese woman; they are courageous, virtuous, filial, and so on. In other words, these characters are the beauties with physical and mental balance. Studying these characters may help us better understand somewhat Vietnamese people's aesthetic conception.

\section{References}

[1] Nguyen Dong Chi. (2015), Collection of Vietnamese Fairy Tales. (Vol. 1 - reprinted). Ho Chi Minh City: Youth Publishing House

[2] Nguyen Dong Chi. (2015), Collection of Vietnamese Fairy Tales. (Vol. 2 - reprinted). Ho Chi Minh City: Youth Publishing House 
[3] Nguyen Tan Dac. (2013), Types, motif and details in Tam Cam Story. Hanoi: Times Publishing house

[4] Nguyen Xuan Duc (2015), Poetics in Fairy tales of Vietnamese. Hanoi: Van Hoa Dan Toc Publishing house.

[5] Dang Quoc Minh Duong. (2017). "Tam Cam untold story: from story to movie", Journal of Art and Culture, Ha noi. The image of the wife and soldier in the Vietnamese folk verses

[6] Nguyen Thi Son Ha \& Dang Quoc Minh Duong. (2019). "The image of the wife and soldier in the Vietnamese folk verses" - in Study literature and culture by type, Publishing House of VNU HCMC.

[7] Multi-authors (2004), Collection of V. Ia. Propp's. vol. 2. Hanoi: Van Hoa Dan Toc Publishing House.

[8] Nguyen Thi Kim Ngan (2021), Beauty and folk aesthetic tastes through singing, http://www.hoakimngan.net/van-hoc-nghethuat/523/nguoi-dep-va-thi-hieu-tham-my-dangian-qua-ca-dao/ retrieve on Jan 12th 2021.

[9] Su B., Shi H., Meng A. \&... (2016), "A Genetic Mechanism for Convergent Skin Lightening during Recent Human Evolution", Molecular Biology and Evolution, Volume 33, Issue 5, 1 May 2016, Pages 1177-1187. 